Техніка і технології тваринництва Engineering and technology livestock

Удк 631.363

https://doi.org/10.37700/enm.2020.3(17).48 - 52

\title{
Удосконалення конструкції вакуумного насоса для доїльних агрегатів
}

\author{
В.С. Хмельовський
}

Національний університет біоресурсів і природокористування України

(м.Київ, Україна) етаil: khmelovskyi@nubip.edu.ua

\begin{abstract}
Приведено аналіз існуючих та нових технічних рішень, які сприяють підвищенню ефективності і надійності роботи вакуумних насосів доїльних агрегатів. Огляд і порівняльна оцінка існуючого доїльного обладнання та установок, свідчить про доцільність використання в їх складі ротаційних пластинчатих вакуумних насосів, як силового елемента. Порівняно з іншими, вони мають досить високий коефіцієнт корисної дії $(0,8-0,9)$, низьку енергоємність $(0,06-0,08$ кВт год/м3), простоту конструкції і обслуговування, можливість безпосереднього з'єднання з електродвигуном. У корпусі насоса, впускний і випускний патрубки насоса до робочої камери, розміщені (в площині поперечного перерізу) близько до радіального напряму. При цьому, впускне та випускне вікна мають протяжність (в напрямі обертання ротора), а вздовж осі корпуса, вона близька до діаметра відповідних патрубків, а протяжність зони стискання повітря помітно збільшена і становить майже $180^{\circ}$. Недоліком такого рішення є зменшення продуктивності та підвищення енергозатрат.

Проведені графічне моделювання, аналіз і узагальнення відомих технічних рішень і результатів досліджень робочого процесу вакуумних насосів ротаційного типу, стосовно обґрунтування їх конструкційно-технологічних параметрів, дозволяють відмітити, що для досягнення поставленої мети доцільно внести такі зміни в конструкцію вакуумної установки:

- збільшити об'єм камери впускного та випускного вікна на внутрішній поверхні корпуса вакуумного насосу. Таке рішення дає можливість швидше заповнити повітрям об'єм, що створюється між двома пластинами ротора та забезпечити більш повний вихлоп. Дані умови сприяють підвищенню продуктивності насоса при тих же значеннях діаметра ротора і частоти його обертання;

- впускний і випускний патрубки розмістити в місцях, де сили, що діють на лопатку, забезпечують максимальне притискання її до корпуса ротора (за ходом обертання ротора в площині її поперечного перерізу), та збільшити протяжність впускного і випускного вікон до такої величини, щоб кут між лопатками забезпечував захват вікон;

- мінімізувати протяжність зони транспортування повітря та його стискування.
\end{abstract}

Ключові слова: вакуумний, насос, камера, впускне вікно, випускне вікно, зона транспортування, ефективність.

Постановка проблеми. Доїння сільськогосподарських тварин є одним з досить трудомістких і найвідповідальніших процесів у технології виробництва продукції тваринництва, а саме молока. Ефективність процесу доїння в значній мірі визначається дотриманням діючих правил машинного доїння та технічною досконалістю засобів механізації, що при цьому використовуються. До складу будь-якої доїльної установки входить вакуумний насос, а також ряд інших елементів (вакуумна регулювальна апаратура з вакуумною магістраллю, вакуумні крани та доїльні апарати) можуть входити також молокопровідна система, засоби обліку, очищення та охолодження молока тощо. Енергетичним (силовим) елементом $€$ вакуумний насос, а ефрективність його роботи забезпечує система урухомлення, фрільтр-глушник, вакуумний балон, вакуумметр і вакуумрегулятор (рис. 1) [1-3]. Насос має створювати вакуумметричний тиск повітря заданих параметрів, з можливістю їх регулювання, а контроль та стабілізацію покладають на вакуумметр і вакуумрегулятор. Саме вакуумне повітряне середовище забезпечує нормальну роботу виконавчих елементів доїльних машин - доїльних апаратів, а також транспортування видоєного молока (у доїльне відро чи загальним молокопроводом в молочне відділення) тощо. I від конструкційно-технологічної досконалості вакуумного насоса, залежить ефективність роботи всього доїльного обладнання та енергомісткість процесу доїння [1-5]. 

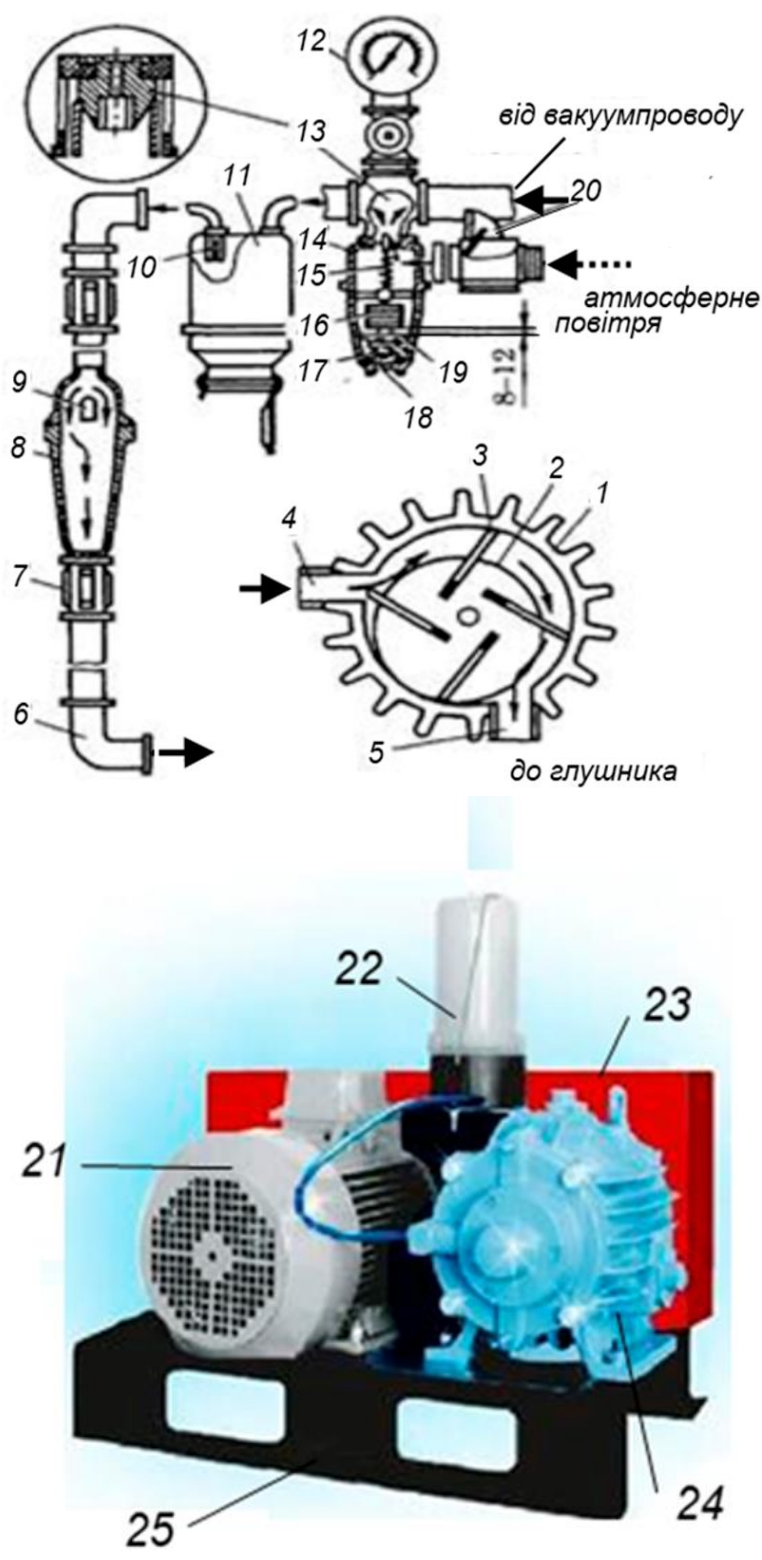

Рис 1. Вакуумна установка УВУ $[2,3]$ : 1 - корпус насоса; 2 - ротор; 3 - лопать; 4 - всмокту-вальний патрубок; 5 - викидний патрубок; 6 - коліно; 7 - муфта; 8 - запобіжник; 9 - зворотний клапан; 10 - клапанпоплавець; 11 - вакуум-балон; 12 - вакуумметр; 13 - клапан регулятора; 14 - корпус ва-

куум-регулятора; 15 - пружина; 16 - вага;

17 - демпферний диск; 18 - стакан; 19 - верх-

ній рівень оливи; 20 - індикатор витрат;

21 - електродвигун; 22 - пристрій для змащування; 23 - огорожа урухомлювача насосу; 24 - вакуумний насос; 25 - рама.

Аналіз останніх досліджень. Огляд і порівняльна оцінка існуючого доїльного обладнання та установок, свідчить про доцільність використання в їх складі ротаційних пластинчатих насосів, як силового елемента. Порівняно з іншими, вони мають досить високий коефріцієнт корисної дії $(0,8-$ $0,9)$, низьку енергоємність $(0,06-0,08$ кВт год/м3), простоту конструкції і обслуговування, можливість безпосереднього з'єднання 3 електродвигуном [6-8]. В сучасних доїльних машинах найчастіше застосовуються уніфріковані вакуумні установки (рис. 1) з ротаційним насосом, який може працювати в двох режимах продуктивності - 45 та 60 м3/год. Проте, насоси мають певні конструкційні недосконалості, які знижують ефективність їх роботи. До таких недоліків відносять правильність визначення фаз розподілу повітря. Невірно обрані фази всмоктування та нагнітання повітря, які обумовлюються фрормою і розташуванням вікон, негативно впливають на робочий процес насоса, його технічні характеристики.

У корпусі насоса, впускний і випускний патрубки, щодо робочої камери, розміщені (в площині поперечного перерізу) близько до радіального напряму. При цьому, впускне та випускне вікна мають протяжність (в напрямі обертання ротора) $[4,5,9]$, а вздовж осі корпуса - відносно невелика, і близька до діаметра відповідних патрубків, а протяжність зони стискання повітря помітно збільшена і становить майже $180^{\circ}$. Недоліком такого рішення $є$ зменшення продуктивності та підвищення енергозатрат (рис. 2).

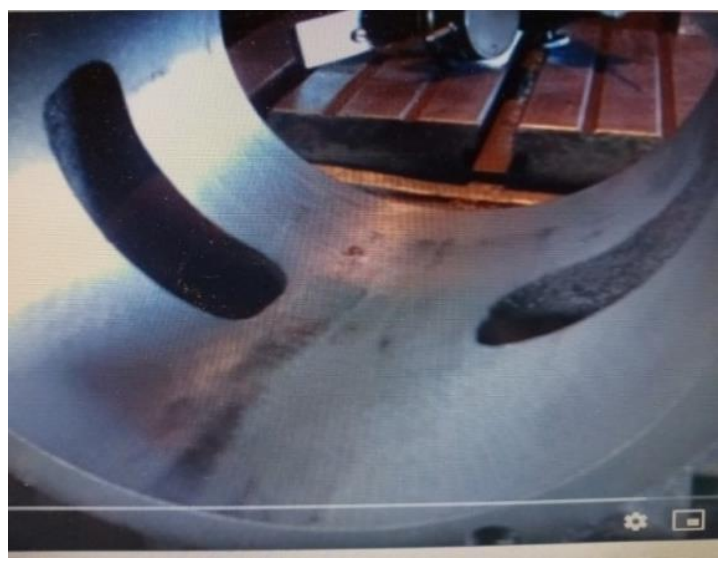

Рис 2. Розміщення впускного

та випускного вікон вакуумного насоса [9]

Згідно $[4,5,6,8,9]$ початок фраз всмоктувння та нагнітання визначається з умови рівності тисків в робочій камері та відповідному вікні, в момент їх з'єднання. Закінчення зазначених фраз повинно відбуватись в момент, коли об'єм робочої камери набуває максимального (всмоктування) та мінімального (нагнітання) значень. Виходячи 3 цього, правильний вибір положення кромок всмоктувального та нагнітального вікон, в першу чергу, залежить від правильного визначення динаміки зміни об'єму робочої камери насоса та тиску в ній, в залежності від кута повороту ротора. 
Мета досліджень - підвищення ефективності і довговічності роботи вакуумного насоса, шляхом удосконалення конструкції його корпуса.

Результати досліджень. Проведені графічне моделювання, аналіз і узагальнення відомих технічних рішень $[7,9]$ і результатів досліджень $[6,8]$ робочого процесу вакуумних насосів ротаційного типу, стосовно обґрунтування їх конструкційно-технологічних параметрів дозволяють відмітити, що для досягнення поставленої мети, доцільно внести такі зміни в конструкцію вакуумної установки:

- збільшити об'єм камери впускного та випускного вікна на внутрішній поверхні корпуса вакуумного насосу (рис. 3). Таке рішення дає можливість швидше заповнити повітрям об'єм, що створюється між двома пластинами ротора та забезпечити більш повний вихлоп [10] і цим самим, сприяє підвищенню продуктивності насоса, при тих же значеннях діаметра ротора і частоти його обертання;


Рис. 3. Вакуумний насос з розширеною площею впускного та випускного вікон [10]
- впускний і випускний патрубки розмістити в місцях де сили, що діють на лопатку, забезпечують максимальне притискання ії до корпуса ротора (за ходом обертання ротора в площині її поперечного перерізу) та збільшити протяжність впускного і випускного вікон до такої величини, щоб кут між лопатками забезпечував захват вікон (рис. 4).

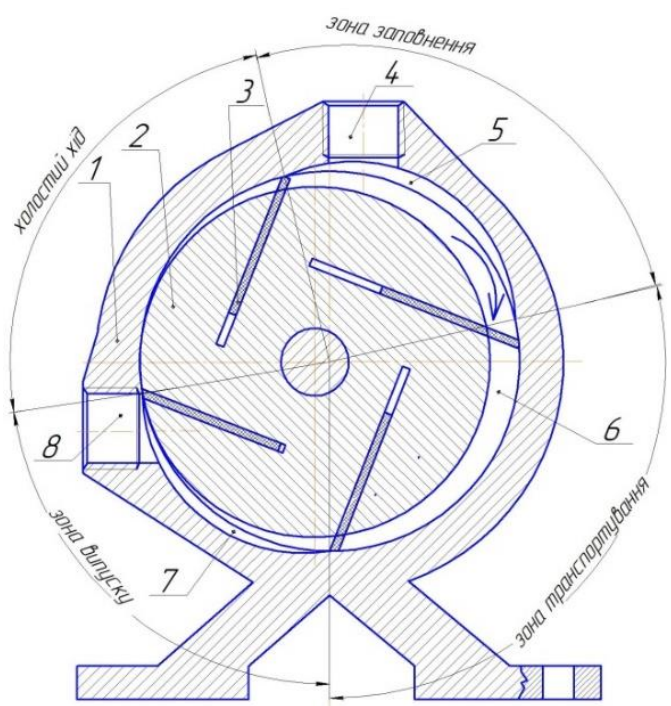

Рис. 4 - Розміщення впускного та випускного вікон вакуумного насоса: 1 - корпус; 2 - ротор;

3 - лопатки; 4 - впускний патрубок;

5 - впускне вікно; 6 - робоча камера;

7 - випускне вікно; 8 - випускний патрубок.

При цьому, враховуючи конструктивні особливості лопатевих вакуумних насосів, протяжність вказаних вікон буде перекриватись простором, який створюється між лопатками.

Результати графічного моделювання, приведеного на рисунку 3, свідчать, що з'єднання з напірним вікном (зона випуску) повинно відбуватися при значенні кута близьким до $80^{\circ}$, а заповнення міжлопатевого простору відбувається в межах $90^{\circ}$, в той час, коли з моменту початку всмоктування до моменту «герметизації» перекриття міжлопатевого простору, лопать проходить близько $186^{\circ}$. При такій компоновці, зона транспортування та стискання повітря буде становити лише 101-103ㅜ, а холостий хід буде становити $85-87^{\circ}$.

Правильність розміщення впускного і випускного патрубків, відносно робочої поверхні, сприяє надходженню в камеру і видаленню з неї повітря, а також скорочується протяжність зони стискання повітря і зменшується його опір. Крім того, в результаті збільшення протяжності вказаних вікон, вдовж осі, дозволить підвищити час і коефіцієнт заповнення камери повітрям. Всі ці рішення будуть сприяти підвищенню продуктивності, довговічності вакуумного насоса та зниженню затрат енергії в процесі його роботи. 
Висновки. Для підвищення ефрективності (збільшення продуктивності, зниження енерговитрат та підвищення довговічності) роботи ротаційного пластинчатого вакуумного насоса необхідно створювати умови максимально можливого заповнення та вивільнення повітря з робочої камери насоса, шляхом збільшення площі живого перерізу, в зоні впускного та випускного патрубків. Мінімізувати протяжність зони транспортування повітря та його стискування.

\section{Література:}

1. Ревенко І.І., Ревенко Ю.І. Удосконалення вакуумної установки доїльних агрегатів. Науковий вісник Національного університету біоресурсів і природокористування України. Серія: Техніка та енергетика АПК. 2015. Вип. 212. Ч. 1. C. $108-113$.

2. Машини та обладнання для тваринництва. І.І. Ревенко, М.В. Брагінець, В.С. Хмельовський. Київ: ТОВ «ЦП Компринт», 2018. 567 с.

3. Машини і обладнання для тваринництва. Ревенко І.І., Хмельовський ВС., Заболотько О.О. та ін. Ніжин, ПП Лисенко М.М. 2017. 304 с.

4. Мжельский Н.И. Вакуумные насосы для доильных установок. Москва: Машиностроение, 1974. 151 c.

5. Механические вакуумные насосы. Е.С. Фролов, И.В. Автономова, В.И. Васильев и др. Москва: Машиностроение, 1989. 288 с.

6. Дудін В.Ю. Фази розподілу повітря ротаційного вакуумного насоса 3 тангенційним розміщенням пластин. Геотехнічна механіка: Міжвід. зб. наук. праць ІН-т геотехнічної механіки ім. М.С.Полякова НАН України. Дніпропетровськ: 2008. Вип. 75. С. 254-258.

7. Патент 46831 (Україна). Вакуумний пластинчасто-роторний насос / А.О. Парієв, С.І. Павленко, С.В. Дубовенко, В.Ю. Дудін. - 11.01.2010, Бюл. № 1.

8. Дудін В.Ю., Плотницький В.І., Алієв Є.Б. Експериментальні дослідження фаз розподілу повітря ротаційного пластинчатого вакуумного нacoca Materiały IX Międzynarodowej naukowi- praktycznej konferencji «Perspektywiczne opracowania są nauką i technikami - 2013». Rolnictwo : Przemyśl. - Nauka i studia, 2013. Volume 32. P. 24-27.

9. https://www.youtube.com/watch?v=jpz3koumO9o

10. https://www.1grc.ru/post/remont-treshchiny-nasosa

\section{References:}

1. Revenko I.I., Revenko Y.I. Improvement of vacuum installation of milking units. Scientific Bulletin of the National University of Life and Environmental Sciences of Ukraine. Series: Engineering and energy of agro-industrial complex. 2015. Vip. 212. Ch. 1. S. $108-113$.

2. Machinery and equipment for animal husbandry. I.I. Ревенко, M.B. Braginets, V.S. Khmelovsky. Kyiv: TsP Comprint LLC, 2018. 567 p.

3. Machinery and equipment for animal husbandry. Revenko I.I., Khmelovsky V.S., Zabolotko O.O. etc. Nizhyn, PP Lysenko M.M. 2017. 304 p.

4. Mzhelsky N.I. Milking machine vacuum pumps. Moscow: Mechanical Engineering, 1974.151 p.

5. Mechanical vacuum pumps. E.S. Frolov, I. V. Avtonomova, V.I. Vasiliev et al. Moscow: Mashinostroenie, $1989.288 \mathrm{p}$.

6. Dudin V.Y. Phases of air distribution of a rotary vacuum pump with tangential arrangement of plates. Geotechnical Mechanics: Interdepartmental. zb. Science. Proceedings of the Institute of Geotechnical Mechanics. MS Polyakova NAS of Ukraine. Dnepropetrovsk: 2008. Issue. 75. pp. 254-258.

7. Patent 46831 (Ukraine). Vacuum plate-rotor pump / A.O. Pariev, S.I. Pavlenko, S.V. Dubovenko, V.Y. Dudin. - 11.01.2010, Bull. № 1.

8. Dudin V.Y., Plotnytsky V.I., Aliyev E.B., Experimental studies of the air distribution phases of a rotary vane vacuum pump Materials of the IX International Scientific-Practical Conference "Perspective studies are science and techniques - 2013". Agriculture: Przemyśl. - Science and studies, 2013. Volume 32. P. 24-27.

9. https://www.youtube.com/watch?v=jpz3koumO9o

10. https://www.1grc.ru/post/remont-treshchiny-nasosa

\section{Аннотация}

\section{Усовершенствование конструкции вакуумного насоса для доильных агрегатов}

\section{В.С. Хмелевский}

Приведен анализ существующих и новых технических решений, способствующих повышению эффективности и надежности работы вакуумных насосов доильных агрегатов. Обзор и сравнительная оценка существующего доильного оборудования и установок, свидетельствуют о целесообразности использования в их составе ротационных пластинчатых вакуумных насосов, как силового элемента. По сравнению с другими, они имеют достаточно высокий коэффрициент полезного действия $(0,8-0,9)$, низкую энергоемкость $(0,06-0,08$ кВт ч/м³), простоту конструкции и обслуживания, возможность непосредственного соединения с электродвигателем. 
В корпусе насоса, впускной и выпускной патрубки насоса в рабочую камеру размещены (в плоскости поперечного сечения) близко к радиальному направлению. При этом, впускное и выпускное окна имеют протяженность (по направлению вращения ротора), а вдоль оси корпуса, она близка к диаметру соответствующих патрубков, а протяженность зоны сжатия воздуха заметно увеличена и составляет почти 180 ․ Недостатком такого решения является уменьшение производительности и повышение энергозатрат.

Проведенные графическое моделирование, анализ и обобщение известных технических решений и результатов исследований рабочего процесса вакуумных насосов ротационного типа, относительно обоснования их конструкционно-технологических параметров, позволяют отметить, что для достижения поставленной цели, целесообразно внести такие изменения в конструкцию вакуумной установки:

- увеличить объем камеры впускного и выпускного окна на внутренней поверхности корпуса вакуумного насоса. Такое решение дает возможность быстрее заполнить воздухом объем, который создается между двумя пластинами ротора и обеспечить более полный выхлоп. Данные условия способствуют повышению производительности насоса при тех же значениях диаметра ротора и частоты его вращения;

- впускной и выпускной патрубки разместить в местах, где силы, действующие на лопатку, обеспечивают максимальное прижимание ее к корпусу ротора (по ходу вращения ротора в плоскости ее поперечного сечения) и увеличить протяженность впускного и выпускного окон до такой величины, чтобы угол между лопатками обеспечивал захват окон;

- минимизировать протяженность зоны транспортировки воздуха и его сжатия.

Ключевые слова: вакуумный насос, камера, впускное окно, выпускное окно, зона транспортировки, эфрфективность.

\section{Abstract}

\section{Improving the design of a vacuum pump for milking units}

\section{V.S. Khmelovskyi}

The analysis of the existing and new technical decisions which promote increase of efficiency and reliability of work of vacuum pumps of milking units is resulted. Review and comparative evaluation of existing milking equipment and installations, indicates the feasibility of using in their composition rotary vane vacuum pumps as a power element. Compared to others, they have a fairly high efficiency $(0.8-0.9)$, low energy consumption $(0.06-0.08 \mathrm{kWh} / \mathrm{m} 3)$, simplicity of construction and maintenance, the possibility of direct connection to the motor. In the pump housing, the inlet and outlet pipes of the pump to the working chamber are located (in the cross-sectional plane) close to the radial direction. In this case, the inlet and outlet windows have a length (in the direction of rotation of the rotor), and along the axis of the housing, it is close to the diameter of the respective nozzles, and the length of the air compression zone is significantly increased and is almost 180o. The disadvantage of this solution is to reduce productivity and increase energy consumption.

The conducted graphic modeling, analysis and generalization of known technical solutions and results of researches of working process of vacuum pumps of rotary type, concerning substantiation of their design and technological parameters, allow to note that for achievement of the set purpose it is expedient to make such changes in a vacuum installation design:

- increase the volume of the intake and exhaust chamber on the inner surface of the vacuum pump housing. This solution allows the volume created between the two rotor plates to be filled with air faster and to provide a fuller exhaust. These conditions help to increase the performance of the pump at the same values of the diameter of the rotor and its speed;

- place the inlet and outlet pipes in places where the forces acting on the blade provide maximum pressure to the rotor body (as the rotor rotates in the plane of its cross section), and increase the length of the inlet and outlet windows to such an extent that the angle between blades provided capture of windows;

- minimize the length of the air transportation and compression zone.

Keywords: vacuum, pump, chamber, inlet window, outlet window, transportation zone, efficiency.

\section{Бібліографічне посилання/ Bibliography citation: Harvard}

Khmelovskyi, V. S. (2020) 'Improving the design of a vacuum pump for milking units', Engineering of nature management, (3(17), pp. 48 - 52.

Подано до редакції / Received: 06.09.2020 